\title{
Investigating the Type of Student Engagement That Exists in English Classrooms of Public Basic Schools in Ghana
}

\author{
Gertrude Afiba Torto \\ Department of Basic Education, University of Cape Coast, Cape Coast, Ghana \\ Email: gertrude.torto@ucc.edu.gh
}

How to cite this paper: Torto, G. A. (2020). Investigating the Type of Student Engagement That Exists in English Classrooms of Public Basic Schools in Ghana. Open Journal of Social Sciences, 8, 69-83. https://doi.org/10.4236/jss.2020.89005

Received: July 27, 2020

Accepted: September 4, 2020

Published: September 7, 2020

Copyright (๑) 2020 by author(s) and Scientific Research Publishing Inc. This work is licensed under the Creative Commons Attribution International License (CC BY 4.0).

http://creativecommons.org/licenses/by/4.0/

\section{(c) (i) Open Access}

\begin{abstract}
Current studies on student engagement and achievement posited that there are three dimensions of student engagement and there is a correlation between the three dimensions of student engagement and achievement. Several researches conducted in Ghana have looked at aspects of student engagement. However, the issue of poor academic performance continues to be a huge challenge. It is imperative therefore to conduct a study to find out the type of student engagement that exists in the public basic schools, in order to find out the underlying factor that impedes good performance in these schools as a way of finding solution to the challenge of poor performance. The study employed a quantitative approach of inquiry, using 61 English language teachers in the Cape Coast metropolis in Ghana. The data was collected by a five-point Likert Scale questionnaire which was analysed using descriptive statistics (Means and Standard Deviation). The study found out that, though there are traits of the three dimensions of student engagement, the dominant dimension was the Emotional. Thus, in Cape Coast, the three dimensions are not at play in the English classrooms so achievement could not happen.
\end{abstract}

\section{Keywords}

Behavioural Engagement, Cognitive Engagement, Emotional Engagement, English, Junior High School

\section{Introduction}

The teaching and learning of English in public basic schools in Ghana continue to attract concerns of stakeholders of education. There is the challenge of low reading, wrong usage of English vocabulary, poor spelling and poor writing skills (Akowuah, Patnaik, \& Kyei, 2018; Chief Examiner's Report, 2016; Dadzie \& Bo- 
siwah, 2015) in classrooms across the country. Stakeholders view these as some of the reasons for the poor performances of students at the Basic Education Certificate Examinations (BECE) English language paper. The Chief Examiners' report for English language continues to lament the poor performance of candidates at the BECE. Among the candidates' weaknesses were the "display of lack of appropriate vocabulary items which hindered their ability to express themselves clearly and meaningfully", candidates' "grammatical and syntactical errors which obtruded in their answers thereby significantly diminishing their marks" and others. As a way of suggesting remedies, the Chief Examiner stated among others that, students should be made to do a lot of exercises on essay writing, perhaps, to equip them to construct meaningful and correct sentences (Chief Examiner's Report, 2018). This report suggests that, for the chief examiner, the students being immersed in constant class work alone could improve their performance greatly.

In Ghana's basic schools, a teacher who teaches English at the Junior High School (JHS) level, teaches all the aspects of the subject; reading, writing, oral language, literature and grammar whilst instructing students in English (L2), the language of instruction at that level of education. It is worthy to note that, these students have received instruction earlier on in their mother language at the lower primary level and so might have grasped concepts taught while at the same time learning the L2 as a subject. Thus, by the time students get to the upper primary levels, it is assumed that, they might have grasped enough vocabulary to learn in the L2 in order to use the elements learned to write better in English.

A teacher, who is committed to teaching, should be able to give close monitoring, adequate pacing and classroom management as well as clearly present concepts in well-structured lessons. Such a teacher should be able to give feedback to students to direct them in their learning. It therefore takes the well trained teacher who is also committed to duty, to provide a well-structured classroom management which is key to direct instruction, supportive climate and individualised instruction as well as cognitive activation which includes the use of deep content, higher order thinking tasks and other demanding activities (Klieme, Pauli, \& Reusser, 2009).

The Ghana Education Service (GES) has within it a hierarchy of personnel who see to the day to day running of schools. At the basic level category, there are Circuit Supervisors (C.S) whose duty it is to supervise the activities of schools placed within their jurisdiction so that there will be a smooth running of those schools. The C.S therefore works in collaboration with the head teachers of the schools and then also acts as a link between the GES office and the schools he/she oversees. Among the roles and responsibilities of the C.S according to the Ghana Education Service (2009) are that they must promote effective teaching and learning in the basic schools, interpret educational policies to teachers, promote effective school management, organize in-service training for teachers and then monitor the achievement and performance of pupils and staff. These responsibilities presuppose that a C.S should frequent the schools under his/her 
management to see to it that both teachers and pupils are regular and punctual to school and that teaching goes on well in order for the pupils to experience maximum learning. The C.S then should be a person who is knowledgeable in the teaching and learning process and should visit classrooms at random when teaching and learning is going on, so as to realise at first hand, the strengths and weaknesses of teachers in their delivery of the subject matter.

The situation where the C.S comes round the schools only to count class exercises becomes a problem as it sends the school into a disadvantaged position. I have realized as a teacher teaching in Government basic schools for many years, that circuit supervisors for basic schools visit the schools to count the number of exercises given to pupils within a specific time instead of sitting in on-going lessons to assess the teacher's teaching so as to offer assistance where need be. Head teachers have also been tasked by their C.S to collect the number of exercises teachers give their pupils. Teachers whose number of exercises meets a certain number are commended whereas teachers whose number of exercises does not reach that required number are queried. Both the C.S and head teachers keep telling teachers to set more exercises for their pupils since that will keep them engaged and equip them with the skill to answer questions and thereby do better at the BECE. This heavy reliance on the number of exercises lead teachers to set more exercises for pupils to answer without spending time explaining concepts to students. There is also the impression created that, it is only the exercises given that improves students' performance.

Students at the JHS have received instruction in their mother language in their early years of education and it is believed that, they have grasped the foundation of concepts as well as grasped enough vocabulary to read and write in English. It is therefore expected that, they will perform better, using Cummins' (1979) Linguistic Interdependence Theory as a reference. A lot of research work conducted on the poor performance of students at the basic school in Ghana revealed challenges that resulted in poor performance of students. Whilst some researchers blamed the poor performance on lack of supervision by head teachers, class size, lack of teaching learning materials, heavy chores at home, lack of support from the home, others cited the lack of commitment to work by teachers as some of the contributory factors that lead to poor performance of students (Butakor \& Dziwornu, 2018; Abdallah, Fuseini, Abudu, \& Nuhu, 2014; Baidoo-Anu, 2017; Etsey, 2005). Comparing these factors found out by researchers in Ghana, which are either predominantly behavioural or emotional in nature, with current research on academic performance of students conducted elsewhere outside Ghana, it has come to light that, factors such as a combination of the various dimensions of class engagement (bahavioural, cognitive and emotional) improves overall performance in academic work and not just a part of it. If after all the studies conducted in Ghana concerning, students' non-performance, students are still not performing well in examinations, then there is the need for a paradigm shift where other factors should be investigated to help the stakeholders of Ghana's education, find out exactly what the challenge is, as there could be an 
underlying factor impeding student's success. The type or types of class engagement that are in use in these schools should be investigated in order to understand the background of students' poor performance.

This study therefore will bring to light the type of student engagement that exists in public basic schools in the Central Region of Ghana as a way of understanding the background of students' poor performance so as to ameliorate it.

The study was guided by one research question.

\section{Research Question}

1) What type of student engagement exists in public basic schools in the Central Region of Ghana in that there are three types of student engagements which together result in good performance?

This study was delimited to the public JHS in the Central Region of Ghana.

\section{2) Review of Related Literature}

\section{Student/Class Engagement}

Student Engagement is defined by Taylor, Hunter, Melton, \& Goodwin (2011), as students' expression of opinions and behaviours which are as a result of the various methods and techniques teachers employ in the teaching and learning situation. These methods and techniques are translated into learning activities that equip students and develop them through participation in the activities (Charles, Bustard, \& Black, 2009). This is to say that class discussions and other methods that teachers bring on board in the teaching and learning process, all things being equal, lead to learning since school engagement of students has an influence on their learning achievement (Wonglorsaichon, Wongwanich \& Wiratchai, 2014). As Chen, 2005; Finn \& Rock, 1997; Osterman, 2000; Wang \& Pomerantz, 2009 posit, Effective learning results when students are effectively engaged in classroom learning activities. This statement also means that, when teachers only set many exercises for students to do without taking the time to discuss the concepts well may not result in effective learning because students may not be engaged effectively.

Fredricks, Blumenfeld, \& Paris (2004) have identified three types of Student Engagement which are: Behavioural, Emotional and Cognitive Engagements. The behavioural engagement considers the participations of students in the classroom as well as other extracurricular activities. This aspect of student engagement focuses more on both the pupil and the teacher's role in the classroom and outside the classroom but within the enactment of the school's curriculum; how students participate in lessons, how teachers carry out their duties in the classroom, what teachers expect from students in the teaching and learning enterprise. The emotional engagement considers the students reactions to teachers, classmates, academic work and the school. When students are emotionally engaged, they participate fully in school/class activities. The school/class emotional engagement dwells on the school or class environment/climate. To Jennings \& Greenberg (2009), “when teachers are sensitive and responsive toward students' 
academic, social and emotional needs, they are more successful academically". However, if a pupil is emotionally troubled from the home, it has a negative bearing on the pupil's achievement at school. The cognitive engagement also considers the students willingness to master concepts. It consists of the amount and type of strategies that learners employ. That is, the meaningful processing of the material to be learned by the student. Greene and Miller (1996) have defined cognitive engagement as one using a strategy to combine both meaningful processing and self-regulatory strategies such as planning and checking one's own work. Meaningful cognitive engagement then dwells on a student being intrinsically motivated to learn since research has proven that, the two variables are positively correlated (Walker, Greene, \& Mansell, 2006). Here, the overt academic standing of the student is focused on. However, all three engagements are necessary for the holistic development of the student. This current study reviews literature on student engagement and its effects on their academic achievement.

\section{Empirical Studies outside Ghana}

Various studies have been conducted to show the evidence of a correlation existing between the three types of engagement and students' academic performance. Wonglorsaichon et al. (2014) in their study where the level of students' school engagement was examined, to test the fit of models of students' school engagement, and to analyze the influence of students' school engagement on their learning achievement by using SEM analysis, found out a number of factors that account for success in academic performance. According to the study, well planned lessons, student dedication to studies, learning environment that is conducive and a good follow-up monitoring and evaluation all contributed to the result of the study.

This study thus revealed a school situation where teachers planned well and carried out their duties accordingly, recognizing their role of establishing student engagement by making students love to come to school. The results of the study also revealed a high level of emotional engagement which also heightened students' cognitive engagement.

The current study however did not seek to find the relationship between the types of engagement and performance, but considered the number of class exercises and compared it with performance at a national examination. Again, there was no need to find out the type of engagement that exists in the public basic schools.

Other studies on the relationship between student engagement and academic achievement have confirmed that there is a correlation between these two constructs. A study by Gunuc (2014) confirms this positive correlation. Gunuc sought to find out the extent to which students' engagement results in students' achievement. It came to light that, "there were significant relationships between the students' academic achievement and student engagement". The researcher found out that "students with a high level of student engagement had higher levels of academic achievement and that those with low level of student engage- 
ment had lower levels of academic achievement" (p. 225). Again regression analysis was done to find out the extent to which student engagement explained achievement. It was concluded that class engagement predicted academic achievement. Thus cognitive, emotional and behavioral engagements have a strong relationship with academic achievement. This statement also means that, for achievement to happen there should be the culmination of all three dimensions of engagements and not just one or two out of the three.

However, a study conducted by Reyes, Brackett, Rivers, White, \& Salovey (2012) on the relationship that exists between Classroom Emotional Climate (CEC), student engagement and academic achievement, found out that, CEC is related to academic performance through student engagement in learning. They concluded that "Authentic instruction cannot take place unless teachers attend to the social and emotional aspects of learning" (Brackett et al., 2009; Zins, Weissberg, Wang, \& Walberg, 2004 as cited by Reyes et al., 2012). The researchers in their study proved that when a classroom climate is conducive, students perform better academically since they are emotionally engaged in the learning process. This assertion then means that, when the classroom climate is not conducive, performance of students will not be good due to the fact that, learners are emotionally involved in their academic work so if they are tensed, learning does not take place. Thus a negative emotional environment leads to a block in the affective filter, bringing about a downward trend in academic progress (Krashen, 2003). The researchers put a lot of stress on the emotional engagement. However, other types of engagement coming together will result in good performance. It is imperative to note that when the school atmosphere is a positive one but that of the home is a negative one, the student, could be emotionally affected which could affect their academic work (Elarousy and Shaqiqi, 2017). It is also worthy to note that, the student needs to be engaged in academic work, as well as be motivated to learn in order to have good achievement. There is the need to have all the three types of student engagement working together so as to increase.

\subsection{Empirical Studies in Ghana}

A few studies have been conducted on student engagement and achievement in Ghana. Ansong, Okona, Bowen, Walker, and Eisensmith (2017), conducted a study on the role of parent, classmate and teacher support in student engagement: evidence from Ghana. In their study, they used the structural equation modeling to examine mediated and unmediated pathways through which parent, teacher and classmate support affect student's Emotional and Behavioural engagement. It was found out that, classmate support has the strongest association with student engagement. This study though could be looked at as focusing on all the three types of engagement, did not give details as to the kind of support parents, teachers and classmates were to give. It was not clear if the supports were material or otherwise.

Baafi (2020) also conducted a study which looked at teacher-student relation- 
ship and student learning outcomes in senior public secondary schools. The study used a sample size of 220 students and 160 teachers who answered a semi-structured questionnaire. After the data were descriptively and inferentially analysed, it was found out that, student engagement thrives well in classrooms which are learner-friendly, where learners have a belonging and feel part of the teaching and the learning process. Even though the researcher focused only on Emotional engagement yet had positive results, Emotional engagement or the relationship between the teacher and the student, without good teaching and student motivation, may not result in high achievement.

\subsection{Gaps in Literature}

Whereas Wonglorsaichon et al. (2014); Gunuc (2014) and Reyes, Brackett, Rivers, White, \& Salovey (2012) found out that there was a correlation between the dimensions of student engagement and achievement, other studies that took place in Ghana looked at aspects (emotional) of students engagement. None of these studies sought to find out the type of engagement that exists in the public JHS in the Cape Coast Metropolis of Ghana. This present study, using teachers of English as participants, is therefore different from other studies in that, this present study sought to find out the type of engagement that exists in public basic schools in the Cape Coast Metropolis in order to find other inherent factors that account for the poor performance of students at the BECE.

\subsection{Methodology}

This is a descriptive study that used a quantitative data collection method and analysis in answering the research question.

\subsection{Population and Sample}

The population for the study was all English language teachers in the public JHS in the Cape Coast metropolis. All teachers of English were selected so as to find out the exact type of engagement in the schools. The teachers were 62 in number.

\section{Sampling Procedure}

The census method was used in selecting all 62 teachers of English in the public schools for the study. The Circuit Supervisors were appointed by government to oversee the public schools, so they visited the schools to ensure that teachers were performing their duties as expected of them. I therefore decided to use all the public basic schools in Cape Coast.

\subsection{Background of Respondents}

The total number of teachers who teach English used in the study was 62, made up of 21 males and 41 females. These teachers were made up of 6 diploma holders, 48 Bachelor degree holders and 9 Master degree holders. Out of the number used for the study, 49 had received training to teach English whereas 13 had received no training. 
The majority of pupils in these schools according to the teachers came from semi-rural backgrounds with their parents being middle to low income earners. The majority of respondents also stated that many pupils helped their parents after school by either selling items or by running errands.

\subsection{Research Instrument}

Questionnaires with a five-point Likert scale were used to collect the responses from teachers in order to answer the research question. All items were closed-ended.

\subsection{Data Analysis}

The data analysis was carried out immediately the collection was done, using means and standard deviation (descriptive statistics).

\section{Results and Discussion}

In order to answer the research question, "What type of student engagement exists in public basic schools in the Central Region of Ghana in that there are three types of student engagements which together result in good performance?", I collected data based on the three dimensions of student engagement: Emotional, Behavioural and Cognitive engagement. Results of the Emotional engagement have been presented in Table 1.

Table 1. How teachers relate to students (Emotional Engagement).

\begin{tabular}{|c|c|c|}
\hline Statement & Mean & S. d \\
\hline I welcome my students always with a smile & 3.7919 & 1.16286 \\
\hline I get close to students who seem to have challenges to help them & 2.1359 & 1.15691 \\
\hline $\begin{array}{l}\text { I avail myself to help all my students at any time in solving their personal } \\
\text { problems }\end{array}$ & 3.9512 & 1.07481 \\
\hline I counsel students only when they open up to me & 2.9946 & 1.36546 \\
\hline $\begin{array}{l}\text { I talk to the head teacher when I realise a student seems to be having } \\
\text { challenges. }\end{array}$ & 2.6125 & 1.30590 \\
\hline I visit students' homes to see them when I do not find them in school & 3.4580 & 1.27646 \\
\hline I talk to students about their future & 3.4146 & 1.28279 \\
\hline $\begin{array}{l}\text { I call/invite parent/guardians to school to discuss their children's } \\
\text { challenges with them }\end{array}$ & 3.4864 & 1.28705 \\
\hline I interact well with all my students to make them feel accepted & 3.1924 & 1.26978 \\
\hline $\begin{array}{l}1 \text { always encourage students to feel good about themselves and never to be } \\
\text { afraid of hard work }\end{array}$ & 2.0650 & 1.28794 \\
\hline $\begin{array}{l}\text { I talk to my students to take their school work seriously as their future } \\
\text { could depend on it }\end{array}$ & 3.0298 & 1.29450 \\
\hline I am always fair but firm in attending to student' issues & 3.3984 & 1.21185 \\
\hline I advise students to respect the views of others & 3.6531 & 1.08046 \\
\hline
\end{tabular}

Source: Field Data (2019), Standard Deviation $=$ SD. 
Table 1 has presented the results of the responses made by the teachers. The statement reflects the relationship between the students and the teacher as well among students. The results reveal a classroom where students are well received and relaxed to do effective school work. The majority of respondents $(\mathrm{M}=3.8$, $S . D=1.16286)$ revealed that, they welcomed their students to class with smiles. When students feel welcomed, they are able to concentrate on the school work because they are less tensed. They feel a sense of belonging to the class and this feeling enables them to settle in to study. Thus, a feeling of belonging a student has within the school environment can support both student engagement and good performance. Respondents again revealed that they availed themselves to helping all their students at any time in solving students' personal problems. This is demonstrated by $(M=3.9512$, S.D = 1.07481). Thus, in such classrooms, students will always be provided with the needed assistance by their teachers in solving issues. The responses by the respondents in fact recorded between an average to an above average affirmation to most of statements on Emotional engagement. For instance, there were responses to statements such as: "I visit students" homes to see them when I do not find them in school' ( $M=3.4580$. S.D = 1.27646), "I talk to students about their future" $(M=3.4146$. S.D = 1.28279), I call/invite parent/guardians to school to discuss their children's challenges with them. $(\mathrm{M}=3.4864$. S.D $=1.28705)$ "I advise students to respect the views of others" $(M=3.6531$. S.D = 1.08046). Even though the data revealed that, the majority of teachers/respondents were caring towards their students, it again revealed that a good number of teachers only counseled students who opened up to them $(\mathrm{M}=2.9946, \mathrm{~S} . \mathrm{D}=1.36546)$.

There was however a low agreement on the statement, "l always encourage students to feel good about themselves and never to be afraid of hard work" which recorded a mean of $2.0650(S . D=1.28794)$. This statement revealed that, teachers actually did not wholly provide a good emotional engagement. If students are not encouraged to feel good about themselves, then students who are encountering domestic issues may be at risk. These students may not have that inner motivation to come out of their shells to overcome certain internal challenges.

Data was also collected to find out about the bahavioural engagement dimension of student engagement. The results have been presented in Table 2.

Table 2 has revealed a low affirmation on the statements on Behavioural engagement. These results show that a greater majority of teachers do not use teaching and learning materials $(M=1.5691$. S.D $=1.01949)$ in their teaching. Teaching materials aid the teacher in explaining concepts better to students and they increase students' success. They are also "very important instruments in helping the learners take part in the learning and teaching processes" (Seven \& Engin, 2007), so the lack of it could affect students' success as proposed by Hoff and Lopus (2014). Therefore, learning will be difficult to take place. There was also the lack of collaboration among students, "students come to class with all 
Table 2. The teaching style and the role of students in class (Behavioural Engagement).

\begin{tabular}{|c|c|c|}
\hline Statement & Mean & Std. D \\
\hline $\begin{array}{l}\text { I use either electronic or non electronic materials or both in my lessons to aid } \\
\text { students' understanding of concepts }\end{array}$ & 1.5691 & 1.01949 \\
\hline I use collaboration often so students learn from one another & 1.4727 & 0.92932 \\
\hline I engage students in discussions of concepts and they respond well & 1.7967 & 1.19981 \\
\hline $\begin{array}{l}\text { I scaffold students in activities that will enable them to come up with the } \\
\text { information by themselves }\end{array}$ & 2.0244 & 1.30299 \\
\hline I link students' prior knowledge and experience to new concepts all the time & 1.8780 & 1.21976 \\
\hline My students come to class with all their books and materials & 1.4727 & 0.92932 \\
\hline $\begin{array}{l}\text { I teach the main concept for the week then for subsequent lessons, I only give } \\
\text { exercise to do }\end{array}$ & 1.8028 & 1.16948 \\
\hline $\begin{array}{l}\text { I discuss the concept with students, present examples, and then I give them } \\
\text { exercises to do }\end{array}$ & 1.5122 & 0.93570 \\
\hline $\begin{array}{l}\text { I stay in the classroom whilst students are doing exercises, in order to offer } \\
\text { assistance to them when need be }\end{array}$ & 1.4580 & 0.92900 \\
\hline $\begin{array}{l}\text { I leave the students to do their work independently since I am preparing them } \\
\text { for BECE }\end{array}$ & 2.0271 & 1.29351 \\
\hline
\end{tabular}

Source: Field Data (2019), Standard Deviation $=$ SD.

their books and materials", "I stay in the classroom whilst students are doing exercises, in order to offer assistance to them when need be", all recording very low means. These results reveal that, in these classrooms, students are not allowed to discuss their thoughts with others; neither do teachers stay in class when students are to complete assignments so as to offer assistance to students who might need their help.

Slightly higher means were recorded for statements such as: "I engage students in discussion of concepts in order to bring out their thoughts and understanding of the concepts" ( $\mathrm{M}=1.7967 . \mathrm{S} . \mathrm{D}=1.19981)$, "I link students" prior knowledge and experience to new concepts all the time" $(\mathrm{M}=1.8780$. S.D $=$ 1.21976), "I teach the main concept for the week then for subsequent lessons", I give exercises. Though these results were slightly higher, they were still very low. These results create a gloomy picture of classrooms where teaching is not done properly so as to result in learning.

In finding out the third dimension of student engagement, Cognitive Engagement, respondents were again asked to demonstrate their level of agreement on some statements. The results have been presented in Table 3 .

The results of data collected on Cognitive engagement reveal that, in most classrooms in the metropolis, cognitive engagement is not very strong. Apart from respondents giving a moderate affirmation to statements such as: "My students ask and answer questions during lessons" $(M=2.4390 . S . D=1.40369)$ and "My students are able to situate the concept in the real world context" ( $\mathrm{M}=$ 2.7174. S.D $=1.53311$ ), all the other statements yielded very low Means to the 
Table 3. How teachers provide feedback and motivate students (Cognitive Engagement).

\begin{tabular}{lcc}
\hline \multicolumn{1}{c}{ Statement } & Mean & Std. D \\
\hline I do continual assessment and give feedback to students regularly & 1.4104 & 0.87099 \\
$\begin{array}{l}\text { I give rewards or punishments to students for their performance in class work } \\
\text { I allow my students to ask in-depth questions during lessons }\end{array}$ & 1.7724 & 1.19200 \\
I include lots of language practice in teaching & 2.4390 & 1.53127 \\
I give remedial teaching to those who perform below average & 1.7073 & 1.17074 \\
My students ask and answer questions during lessons & 1.1707 & 0.95496 \\
My students are able to situate the concept in the real world context & 2.7011 & 1.40369 \\
My students write and respond to issues of learning openly & 2.7174 & 1.53311 \\
My students study on their own and present answered questions to teachers & 1.5625 & 1.05252 \\
for marking & 1.6250 & 1.09277 \\
At the end of each lesson, my students look self-assured and confident & 2.0637 & 0.28969 \\
\hline
\end{tabular}

Source: Field Data (2020), Standard Deviation = SD.

statements. The statements, "I do continual assessment and give feedback to students regularly" and "I give remedial teaching to those who perform below average" both yielded a Means of $1.4104(\mathrm{~S} . \mathrm{D}=0.87099)$ and $1.1707(0.95496)$ which were very low, revealing the type of teaching and learning going on in these classrooms. The result also made it clear that, students could not write and respond to issues of learning openly as a Mean of 1.5625 (S.D = 1.05252) was recorded. The results also revealed that, the majority of teachers do not involve students in language practice in order to sharpen the students' pronunciation as a mean of $1.7073(S . D=1.17074)$ was recorded on the statement.

\section{Discussion}

The results of this study have revealed classrooms where there is an average relationship between teachers and students. teachers try to make students feel wanted within the school or class environment, however, these teachers only assist students who are able to open up to them. In the situation where students feel threatened to open up to teachers, theses students would not get the needed support. Thus, teachers, who are supposed to be stand-in parents, do not perform their duties well. This lack of attention towards all students could negatively affect them psychologically, resulting in poor academic work (Febrilla, Warokka, \& Abdullah, 2011). Students are not also encouraged to feel good about themselves in order to work harder. This situation could create anxiety on the part of students who might be having poor self-image and result in negative impacts on their productive and perceptive language skills (Pishghadam, Zabetipour, \& Aminzadeh, 2016).

The study again revealed classrooms where teachers taught without teaching and learning materials. The classrooms also lacked students collaborating in academic work for better grasping. There was also no proper discussion of con- 
cepts revealing a poor academic environment where students only received from teachers without contributing their ideas to class discussions.

The study further reveals classrooms where students are not being motivated either intrinsically or extrinsically to study. When feedback on student's class work is provided and students get to know and understand their errors, they tend to avoid such errors in subsequent exercises. The majority of teachers do not involve students in language practice in order to sharpen the students' pronunciation as recorded by a Mean of 1.7073 (S.D =1.17074) was recorded on the statement. Gilakjani and Sabouri (2016) found out that, "Individuals who have acceptable pronunciation can easily improve their language skills better than those who have weak pronunciation". Therefore, when students are engaged in frequent pronunciation, their language skills tend to improve and this may motivate them to study. Definitely, students who have issues with pronunciation may not have the desire to study the subject.

The issue of remedial teaching also aids the student to understand concepts better, which leads to the student gaining confidence in him/her to study. Lack of it will definitely affect the student negatively. The result on the statement "I give remedial teaching to those who perform below average" revealed a mean of 1.17074 (S.D $=0.95496)$, showing a low agreement on the statement. This result proves that, the majority of teachers at the JHS level do not provide remedial teaching to their low-performing students. This lack of remedial teaching could prevent students from having that motivation to learn the subject.

\section{Conclusion}

The study has brought to the fore the fact that in the public JHS in the metropolis, the three dimensions of student engagement is not at play in English classrooms. The results of the study have revealed classrooms where there is a moderate Emotional engagement at the expense of the other two dimensions: Behavioural and Cognitive. The study has revealed that, though teachers set a lot of exercises for students to do, some underlying factors prevent these students from doing well academically. For instance, the study revealed that scaffold instruction, collaboration and remedial teaching are almost nonexistent.

Teachers teach with little or no teaching aids as well. In this case, struggling students do not get the assistance they need. Students only get to redo the exercises they got wrong by either the teacher explaining the procedure or providing the correct answer. If the teacher only considers giving students class exercises, marks them, discusses the correct answers with students and then tells them to do their corrections, then the cognitive engagement is lost as students do not get motivated to learn by themselves. They do not put in much effort to study and to truly understand the concept (Rotgans \& Schmidt, 2011); therefore students are bound to fail academically. Even though Reyes et al. (2012) found out that, a good Classroom Emotional Climate improves students' learning, Gunuc (2014); Wonglorsaichon et al. (2014) posited that, the other dimensions of students' en- 
gagement should be present and working together as there is a positive correlation between the three dimensions of student engagement and achievement. The absence of the three dimensions of student engagement then becomes a huge setback to achievement. There can therefore not be good achievement since all the three dimensions are not working together (Wonglorsaichon et al., 2014). Thus, it can be concluded that the fundamental factor impeding academic success for students at the B.E.C.E is the fact that, the three dimensions of student engagements, are non-existent. For students' academic performance to be improved, teachers should ensure that all the dimensions of student engagement are working well together.

\section{Limitation}

The study was a descriptive survey, collecting data by means of only questionnaires. Perhaps, conducting a case study, using fewer schools and employing qualitative means of data collection and data analysis could have given a diverse report on student engagement.

\section{Conflicts of Interest}

The author declares no conflicts of interest regarding the publication of this paper.

\section{References}

Abdallah, H., Fuseini, M. N., Abudu, A. M., \& Nuhu, Y. (2014). Dilemma of Basic School Pupils in Northern Ghana with Respect to Their Learning Context. Educational Research International, 2014, Article ID: 140737. https://doi.org/10.1155/2014/140737

Akowuah, J. A., Patnaik, S., \& Kyei, E. (2018). Evidence-Based Learning of Students' Performance in English Language in Adu Gyamfi Senior High School in the Sekyere South District of Ghana. Cogent Social Sciences, 4, 1. https://doi.org/10.1080/23311886.2018.1503577

Ansong, D., Okumu, M., Bowen, G. L., Walker, A. M., \& Eisensmith, S. R. (2017). The Role of Parent, Classmate, and Teacher Support in Student Engagement: Evidence from Ghana. International Journal of Educational Development, 54, 51-58. https://doi.org/10.1016/j.ijedudev.2017.03.010

Baafi, R. K. A. (2020). Teacher-Student Relationship and Student Learning Outcomes in Senior Public Secondary Schools in Ghana. European Journal of Education Studies, 6, 147-161.

Baidoo-Anu, D. (2017). Perceived Factors Responsible for Poor Academic Performance of Junior High School Pupils in Asikuma Circuit of Asikuma-Odoben-Brakwa District. A Thesis, Cape Coast: The University of Cape Coast. https://doi.org/10.9734/JESBS/2018/39617

Brackett, M. A., Patti, J., Stern, R., Rivers, S. E., Elbertson, N. A., Chisholm, C. et al. (2009). A Sustainable, Skill-Based Approach to Building Emotionally Literate Schools. In M. Hughes, H. L. Thompson, \& J. B. Terrell (Eds.), Handbook for Developing Emotional and Social Intelligence: Best Practices, Case Studies, and Strategies (pp. 329-358). San Francisco, CA: Pfeiffer.

Butakor, P. K., \& Dziwornu, M. (2018). Teachers Perceived Causes of Poor Performance 
in Mathematics by Students in Basic Schools from Ningo Prampram, Ghana. The Journal of Social Sciences Research, Academic Research, 4, 423-431.

Charles, M. T., Bustard, D. W., \& Black, M. (2009). Experiences of Promoting Engagement in Game-Based Learning. In Proceedings of ECGBL 2009: European Conference on Games Based Learning (pp. 397-403). Kidmore End: Academic Conferences.

Chen, J. J. L. (2005). Relation of Academic Support from Parents, Teachers, and Peers to Hong Kong Adolescents' Academic Achievement: The Mediating Role of Academic Engagement. Genetic, Social, and General Psychology Monographs, 131, 77-127. https://doi.org/10.3200/MONO.131.2.77-127

Chief Examiners' Report (2016). General Resume of the Chief Examiners' Reports on the Basic Education Certificate Examination for School Candidates, 2016. Accra: West African Examination Council.

Chief Examiners' Report (2018). General Resume of the Chief Examiners' Reports on the Basic Education Certificate Examination for School Candidates, 2018. Accra: West African Examination Council.

Cummins, J. (1979). Linguistic Interdependence and the Educational Development of Bilingual Children. Review of Educational Research, 49, 222-251. https://doi.org/10.3102/00346543049002222

Dadzie, G., \& Bosiwah, L. (2015). Spelling Errors among Junior High School Students in the Cape Coast Metropolis. Journal of Language, Linguistics and Literature, 1, 46-54. https://doi.org/10.11648/j.ijeedu.20150403.12

Elarousy, W., \& Shaqiqi, W. (2017). Effect of Physical Abuse on Academic Achievement among Secondary School Female Students in Jeddah. Journal of Community \& Public Health Nursing, 3, 166. https://doi.org/10.4172/2471-9846.1000166

Etsey, K. (2005). Causes of Low Academic Performance of Primary School Pupils in the Shama Sub-Metro of Shama Ahanta East Metropolitan Assembly (SAEMA) in Ghana. In the Regional Conference on Education in West Africa. Dakar.

Febrilla, I., Warokka, A., \& Abdullah, H. H. (2011). University Students' Emotional State and Academic Performance: New Insights of Managing Complex Cognitive. Journal of e-Learning and Higher Education, 2011, Article ID: 879553. https://doi.org/10.5171/2011.879553

Finn, J. D., \& Rock, D. A. (1997). Academic Success among Students at Risk for School Failure. The Journal of Applied Psychology, 82, 221-234. https://doi.org/10.1037/0021-9010.82.2.221

Fredricks, J. A., Blumenfeld, P. C., \& Paris, A. H. (2004). School Engagement: Potential of the Concept, State of the Evidence. Review of Educational Research, 74, 59-109. https://doi.org/10.3102/00346543074001059

Ghana Education Service (2009). Roles and Responsibilities Standards for Inspectors \& Circuit Supervisors. GES, Inspectorate Division.

Gilakjani, A. P., \& Sabouri, N. B. (2016). Why Is English Pronunciation Ignored by EFL Teachers in Their Classes? International Journal of English Linguistics, 6, 195-208. https://doi.org/10.5539/ijel.v6n6p195

Greene, B. A., \& Miller, R. B. (1996). Influences on Achievement: Goals, Perceived Ability, and Cognitive Engagement. Contemporary Educational Psychology, 21, 181-192. https://doi.org/10.1006/ceps.1996.0015

Gunuc, S. (2014). The Relationships between Student Engagement and Their Academic Achievement. International Journal on New Trends in Education and Their Implications, 5, 216-231. http://www.ijonte.org 
Hoff, J., \& Lopus, J. S. (2014). Does Student Engagement Affect Student Achievement in High School Economics Classes? Paper Presented at Annual Meetings of the Allied Social Science Association. Philadelphia.

Jennings, P. A., \& Greenberg, M. T. (2009). The Prosocial Classroom: Teacher Social and Emotional Competence in Relation to Student and Classroom Outcomes. Review of Educational Research, 79, 491-525. https://doi.org/10.3102/0034654308325693

Klieme, E., Pauli, C., \& Reusser, K. (2009). The Pythagoras Study: Investigating Effects of Teaching and Learning in Swiss and German Mathematics Classrooms. In The Power of Video Studies in Investigating Teaching and Learning in the Classroom (pp. 137-160). Munster: Waxmann.

Krashen, S. (2003). Explorations in Language Acquisition and Use. Portsmouth, NH: Heinemann.

Osterman, K. E. (2000). Students' Need for Belonging in the School Community. Review of Educational Research, 70, 323-367. https://doi.org/10.3102/00346543070003323

Pishghadam, R., Zabetipour, M., \& Aminzadeh (2016). Examining Emotions in English Language Learning Classes: A Case of EFL Emotions. Issues in Educational Research, 26, 508-527.

Reyes, M. R., Brackett, M. A., Rivers, S. E., White, M., \& Salovey, P. (2012) Classroom Emotional Climate, Student Engagement, and Academic Achievement. Journal of Educational Psychology, 104, 700-712. https://doi.org/10.1037/a0027268

Rotgans, J. I., \& Schmidt, H. G. (2011). Cognitive Engagement in the Problem-Based Learning Classroom. Advances in Health Sciences Education, 16, 465-479. https://doi.org/10.1007/s10459-011-9272-9

Seven, M. A., \& Engin, A. O. (2007). The Importance and Effect of Using Aid Materials in Foreign Language Teaching. https://files.eric.ed.gov/fulltext/ed497456.pdf

Taylor, S. A., Hunter, G. L., Melton, H., \& Goodwin, S. A. (2011). Student Engagement and Marketing Classes. Journal of Marketing Education, 33, 73-92. https://doi.org/10.1177/0273475310392542

Walker, C. O., Greene, B. A., \& Mansell, R. A. (2006). Identification with Academics, Intrinsic/Extrinsic Motivation, and Self-Efficacy as Predictors of Cognitive Engagement. Learning and Individual Differences, 16, 1-12. https://doi.org/10.1016/j.lindif.2005.06.004

Wang, Q., \& Pomerantz, E. M. (2009). The Motivational Landscape of Early Adolescence in the United States and China: A Longitudinal Investigation. Child Development, 80, 1272-1287. https://doi.org/10.1111/j.1467-8624.2009.01331.x

Wonglorsaichon, B., Wongwanich, S., \& Wiratchai, N. (2014). The Influence of Students School Engagement on Learning Achievement: A Structural Equation Modeling Analysis. Procedia-Social and Behavioral Sciences, 116, 1748-1755.

https://doi.org/10.1016/j.sbspro.2014.01.467

http://www.sciencedirect.com

Zins, J. E., Weissberg, R. P., Wang, M. C., \& Walberg, H. J. (2004). Building Academic Success on Social and Emotional Learning: What Does the Research Say? New York: Teachers College Press. 